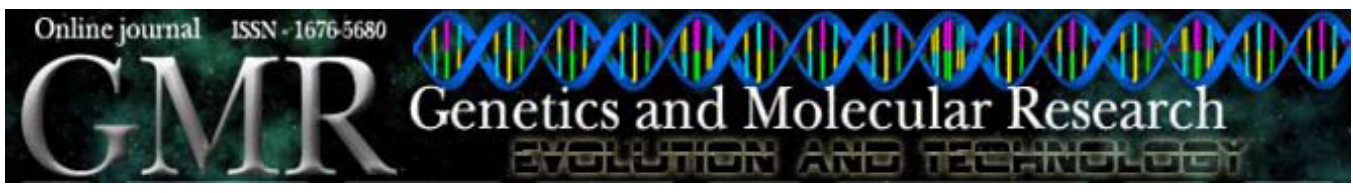

\title{
Improvement of a popcorn population using selection indexes from a fourth cycle of recurrent selection program carried out in two different environments
}

\author{
A.T. Amaral Júnior ${ }^{1}$, S.P. Freitas Júnior ${ }^{1}$, R.M. Rangel ${ }^{1}$, G.F. Pena ${ }^{1}$, \\ R.M. Ribeiro ${ }^{1}$, R.C. Morais $^{1}$ and A.R. Schuelter ${ }^{2}$ \\ ${ }^{1}$ Laboratório de Melhoramento Genético Vegetal, \\ Universidade Estadual do Norte Fluminense Darcy Ribeiro, \\ Campos dos Goytacazes, RJ, Brasil \\ ${ }^{2}$ Laboratório de Biotecnologia, Universidade Paranaense, Toledo, PR, Brasil \\ Corresponding author: A.T. Amaral Júnior \\ E-mail: amaraljr@uenf.br
}

Genet. Mol. Res. 9 (1): 340-347 (2010)

Received November 3, 2009

Accepted December 4, 2009

Published March 2, 2010

\begin{abstract}
We estimated genetic gains for popcorn varieties using selection indexes in a fourth cycle of intrapopulation recurrent selection developed in the campus of the Universidade Estadual do Norte Fluminense. Two hundred full-sib families were obtained from the popcorn population UNB-2U of the third recurrent selection cycle. The progenies were evaluated in a randomized block design with two replications at sites in two different environments: the Colégio Estadual Agrícola Antônio Sarlo, in Campos dos Goytacazes, and the Empresa de Pesquisa Agropecuária do Estado do Rio de Janeiro (PESAGRO-RIO), in Itaocara, both in the State of Rio de Janeiro. There were significant differences between families within sets in all traits, indicating genetic variability that could be exploited in future cycles. Thirty full-sib families were selected to continue the program. The selection indexes used to predict the gains were those of Mulamba and Mock, Smith and Hazel. The best results were obtained with the
\end{abstract}


Mulamba and Mock index, which allowed the prediction of negative gains for the traits number of diseased ears and ears attacked by pests, number of broken plants and lodging, as well as ears with poor husk cover. It also provided higher gains for popping expansion and grain yield than with the other indexes, giving values of 10.55 and $8.50 \%$, respectively, based on tentatively assigned random weights.

Key words: Zea mays; Intrapopulation selection; Genetic gains; Selection indexes

\section{INTRODUCTION}

To select cultivars for breeding procedures based on only one trait is nowadays not ideal, since on the one hand producers are interested in the yield capacity of the plant material, while the consumer on the other hand is concerned with the quality of the food product. For popcorn, this situation directly involves at least two traits: grain yield and popping expansion. The first is of primary importance for the producer. Popping expansion, in turn, is highly important for consumers who prefer soft popcorn, apart from a snow-white color of popped corn and few unpopped kernels (Pacheco et al., 1998; Sawazaki, 2001; Daros et al., 2004b; Aguiar et al., 2008; Rangel et al., 2007, 2008; Vilela et al., 2008; Freitas Júnior et al., 2006, 2009; Munhoz et al., 2009).

It is not a simple task to combine high yield capacity with good popping expansion. Quite on the contrary, the negative correlation between these traits (Pacheco et al., 1998; Pereira and Amaral Júnior, 2001; Daros et al., 2004b; Vieira et al., 2009a) hampers the efficiency of the work of breeders, mainly if truncated selection is used (Freitas Júnior et al., 2006; Scapim et al., 2006; Tardin et al., 2007; Santos et al., 2007, 2008; Vieira et al., 2009b).

To circumvent this problem, the use of selection indexes seems appropriate, where the statistical strength outweighs the negative correlation and allows the selection of high-yielding progeny with high grain-popping quality in recurrent selection programs.

Selection indexes are multivariate techniques that combine information of different traits of agronomic interest with the genetic properties of a population. Using the selection indexes, numerical values are determined serving as an additional, theoretical trait, resulting from the combination of particular traits defined by the breeder, which should be maintained under simultaneous selection (Cruz and Carneiro, 2003; Bezerra Neto et al., 2006; Santos et al., 2007).

In popcorn, the use of selection indexes is rare. In one example, the index of Smith (1936) and Hazel (1943) was successfully used by Granate et al. (2002) in the population CMS43 to predict the desired progress in the traits plant height, yield and popping expansion, when using tentatively attributed random weights. Viana and Matta (2003) also obtained satisfactory results for popping expansion and yield using the index of Elston (1963). Besides, in the C3 cycle of intrapopulation recurrent selection in the UNB-2U variety, to select the 30 superior half-sib families, Santos et al. (2007) obtained the best genetic gains using the index of Mulamba and Mock (1978), with values of 7.16\% for popping expansion and $10.00 \%$ for grain yield.

But for the success of an intrapopulation recurrent selection in popcorn, the breeders need to be concerned with the genetic base of the base-population under selection. In fact, the reduced genetic base of the crop, which may result from the selections of corn types such as flint (Kantety et al., 1995), is an aspect that has concerned investigators when implementing 
breeding programs. In relation to a base-population of popcorn for breeding in the tropics, Miranda et al. (2008) concluded that although it is possible to increase grain yield using local genotypes, it is difficult to breed commercial hybrids from these genotypes in Brazil due to poor performance in terms of popping expansion.

The Universidade Estadual do Norte Fluminense Darcy Ribeiro (UENF) has been developing a recurrent selection program with popcorn, with the aim of releasing a variety with desirable traits, adapted to the northern and northwestern regions of the State of Rio de Janeiro. The program was initiated with the evaluation of the potential of the population UNB-2U by Pereira and Amaral Júnior (2001) and the observation that the strategy of recurrent selection among full-sib families is the most efficient for breeding improved varieties, for both expansion volume and grain yield.

In view of the selection potential of UNB-2U, three recurrent selection cycles were performed with respective selection gains in grain yield and popping expansion of 10.39 and $4.69 \%$ in the first cycle (Daros et al., 2002), 26.95 and 17.80\% in the second cycle (Daros et al., 2004a), and 10.00 and $7.16 \%$ in the third cycle (Santos et al., 2007), without any evidence of a narrowing of the genetic base of the population, as determined by Vilela et al. (2008).

This study was conducted with the aim of selecting 30 superior full-sib families for traits of interest for the popcorn breeding program at UENF. Analytical procedures of the selection indexes of Mulamba and Mock (1978) and Smith (1936) and Hazel (1943) were used in order to accurately identify families that can induce effective increases in the concentration of favorable alleles, for the release of superior varieties for producers in the northern and northwestern regions of the State of Rio de Janeiro, Brazil.

\section{MATERIAL AND METHODS}

The competition tests were conducted in the 2005/2006 growing season at two sites: the Colégio Estadual Agrícola Antônio Sarlo, in Campos dos Goytacazes, and the Experimental Station of PESAGRO-RIO in Itaocara, both in the northern part of the State of Rio de Janeiro, $110 \mathrm{~km}$ from each other.

Complete randomized block designs were used with two replications in eight sets, each consisting of 25 full-sib families and the control BRS Angela variety. Each family was planted in $5-\mathrm{m}$ long rows, with a spacing of $1.00 \times 0.20 \mathrm{~m}$. The cultivation treatments were performed when necessary, according to the recommendations for the crop.

The following traits were evaluated: i) mean plant height $(\mathrm{PH})$, measured in $\mathrm{cm}$, after silking, from the ground level to the insertion of the flag leaf, in eight healthy plants; ii) mean ear height $(\mathrm{EH})$, measuring the distance in $\mathrm{cm}$, from the ground level to the insertion of the highest ear, in eight healthy plants; iii) mean number of lodged plants (NLP), counting the plants with an inclination angle of more than $45^{\circ}$ with the vertical, at harvest; iv) mean number of broken plants (NBP), counting the plants with a broken stem below the highest ear on each plot, at harvest; v) final stand (FS) expressed by the number of plants in the plot, at harvest; vi) mean number of ears (NE), counting the number of ears collected from each plot; vii) grain yield (GY), determined by weighing the grain after removal from the cob, in $\mathrm{kg} / \mathrm{ha}$; viii) mean weight of ears with grain (EW), obtained by weighing the husked ears, after harvest, expressed as $\mathrm{kg} / \mathrm{ha}$; ix) mean number of diseased ears (ND), expressed by the number of diseased ears in each plot at harvest; $x$ ) mean number of ears attacked by pests (NP), given by 
the number of ears attacked by pests in each plot at harvest; xi) mean number of ears with poor husk cover (EPH), quantified by counting the ears with uncovered tips in each plot, at harvest; xii) mean number of days to flowering (FLOW), measured as the period between planting and release of the styles of $50 \%$ of the plants of the row; xiii) mean weight of 100 grains (W100), 100 randomly selected grains from different plants of each plot weighed on a balance to two decimal places, and xiv) popping expansion (PE), determined in the laboratory, according to the method recommended by Pacheco et al. (1998), using an electric popping device from EMBRAPA-Instrumentação Agropecuária. $\mathrm{PE}$ was measured by the ratio $\mathrm{mL} / \mathrm{g}$, that is, the volume of $30 \mathrm{~g}$ popcorn grain after popping, with two replications for each plot, at a temperature of $270^{\circ} \mathrm{C}$ and popping time of $2.5 \mathrm{~min}$.

The data of the traits were used for the analysis of variance according to the statistical model $\mathrm{Y}_{\mathrm{i} \mathrm{jkl}}=\mu+\mathrm{A}_{\mathrm{i}}+\mathrm{S}_{\mathrm{j}}+\mathrm{AS}_{\mathrm{ij}}+\mathrm{R} / \mathrm{AS}_{\mathrm{ijk}}+\mathrm{F} / \mathrm{S}_{\mathrm{j} 1}+\mathrm{AF} / \mathrm{S}_{\mathrm{ij} 1}+\xi_{\mathrm{ijk} l}$, where $\mu$ is the mean; $\mathrm{A}$ is the fixed effect of the ith environment; $S_{j}$ is the effect of the $\mathrm{j}$ th set; $\mathrm{AS}_{\mathrm{ij}}$ is the effect of the interaction between environments and sets; $\mathrm{R} / \mathrm{AS}_{\mathrm{ijk}}$ is the effect of $\mathrm{k} t h$ replication within the interaction between the ith environment and $\mathrm{j} t h$ set; $\mathrm{F} / \mathrm{S}_{\mathrm{j} 1}$ is the random effect of $\mathrm{i}$ th genotype in the $\mathrm{j}$ th set; $\mathrm{AF} / \mathrm{S}_{\mathrm{ij} 1}$ is the effect of the genotype-environment interaction in the $\mathrm{j} t \mathrm{set}$, and $\xi_{\mathrm{ijkl}}$ is the experimental error. The SAS software (SAS, 1995) was used for the statistical analysis.

The selection indexes used to predict the gains were those of Mulamba and Mock (1978), and the classic index of Smith (1936) and Hazel (1943).

The index of Mulamba and Mock (1978) ranks the genotypes, initially, for each trait, by assigning higher absolute values to those of better performance. Finally, the values assigned to each trait are added, obtaining the sum of the ranks, which indicates the classification of genotypes (Cruz and Carneiro, 2003).

The index of Smith (1936) and Hazel (1943), on the other hand, is based on the solution of the matrix system: $\mathrm{b}=\mathrm{P}-1 \mathrm{Ga}$, where $\mathrm{b}$ is the vector of size $14 \times 1$ of the weighting coefficients of the index to be estimated; P - 1 is the inverse of the matrix of size $14 \times 14$, phenotypic variances and covariances between traits; $G$ is the matrix of size $14 \times 14$, variances and covariances between the genetic traits, and a is a $14 \mathrm{x} 1$ vector of economic weights (Cruz and Carneiro, 2003).

The economic weights were: i) coefficient of genetic variation $\left(\mathrm{CV}_{\mathrm{g}}\right)$; ii) genetic standard deviation $\left(\mathrm{SD}_{\mathrm{g}}\right.$ ); iii) the ratio $\mathrm{CV}_{\mathrm{g}} / \mathrm{CV}_{\mathrm{e}}$, where $\mathrm{CV}_{\mathrm{e}}$ is the coefficient of experimental variation; iv) heritability $\left(\mathrm{h}^{2}\right)$, and $\mathrm{v}$ ) tentatively assigned weights (AEW) with magnitudes of 1,10 , $20,1,100,100,1,1,1,1,1,15,25$, and 15, for the traits NE, ND, NP, EW, GY, PE, W100, FLOW, PH, EH, FS, NBP, NLP, and EPH, respectively, which are optimum values of gains for all traits. They were randomly obtained for different magnitudes. The GENES software (Cruz, 2006) was used to perform the statistical analysis.

\section{RESULTS AND DISCUSSION}

There was a significant effect for all traits in relation to F/S (families within sets), which indicates that there is genetic variability in the population of the fourth recurrent selection cycle in full-sib families. Besides, it was revealed that the objective of improving the UNB-2U population by concentration of favorable alleles was achieved.

Based on the estimated gain percentage predicted for the selection index of Mulamba and Mock (1978) and Smith (1936) and Hazel (1943), using as economic weights $\mathrm{CV}_{\mathrm{g}}$ and $\mathrm{h}^{2}$, 
the gains for the traits ND, NP, FLOW, PH, EH, NBP, NLP, and EPH were negative, which is interesting for population improvement when populations with fewer diseased ears, fewer ears attacked by pests, lower number of broken and lodged plants, and early and shorter plants are desired (Table 1). This last trait is particularly interesting for the northern and northwestern part of the State of Rio de Janeiro because of the strong winds.

\begin{tabular}{|c|c|c|c|c|c|c|c|c|c|c|}
\hline \multirow[t]{2}{*}{ Trait } & \multicolumn{5}{|c|}{ Mulamba and Mock } & \multicolumn{5}{|c|}{ Smith and Hazel } \\
\hline & $\mathrm{CV}_{\mathrm{g}}$ & $\mathrm{SD}_{\mathrm{g}}$ & $\mathrm{CV}_{\mathrm{g}} / \mathrm{CV}_{\mathrm{e}}$ & $h^{2}$ & AEW & $\mathrm{CV}_{\mathrm{g}}$ & $\mathrm{SD}_{\mathrm{g}}$ & $\mathrm{CV}_{\mathrm{g}} / \mathrm{CV}_{\mathrm{e}}$ & $h^{2}$ & AEW \\
\hline $\mathrm{NE}$ & 1.30 & 5.56 & 4.72 & 4.66 & 3.27 & 4.92 & 4.92 & 4.92 & 4.92 & 4.47 \\
\hline ND & -7.24 & -3.27 & -0.23 & -6.55 & -3.96 & -4.59 & -4.59 & -4.59 & -4.59 & -6.66 \\
\hline NP & -0.92 & 0.52 & 2.24 & -0.48 & -2.53 & 0.30 & 0.30 & 0.30 & 0.30 & 0.41 \\
\hline EW & 5.02 & 11.04 & 6.50 & 8.11 & 7.52 & 10.57 & 10.57 & 10.57 & 10.57 & 10.17 \\
\hline GY & 5.11 & 11.60 & 6.47 & 8.86 & 8.50 & 11.17 & 11.17 & 11.17 & 11.17 & 10.98 \\
\hline PE & 2.14 & 1.27 & 9.44 & 5.49 & 10.55 & 1.39 & 1.39 & 1.39 & 1.39 & 0.47 \\
\hline W100 & 1.29 & 2.31 & 1.21 & 2.83 & 0.14 & 2.10 & 2.10 & 2.10 & 2.10 & 2.76 \\
\hline FLOW & -0.69 & -0.59 & 0.66 & -0.38 & -0.86 & -1.21 & -1.21 & -1.21 & -1.21 & -1.00 \\
\hline PH & -1.34 & 0.50 & 2.33 & -1.26 & -0.37 & -0.72 & -0.72 & -0.72 & -0.72 & -0.83 \\
\hline EH & -0.83 & 0.35 & 1.42 & -0.79 & -0.30 & -0.40 & -0.40 & -0.40 & -0.40 & -0.22 \\
\hline FS & 0.52 & 0.74 & 0.60 & 0.80 & 0.60 & 0.72 & 0.72 & 0.72 & 0.72 & 0.68 \\
\hline NBP & -5.01 & 1.44 & 0.93 & -2.32 & -2.48 & 2.53 & 2.53 & 2.53 & 2.53 & 3.56 \\
\hline NLP & -26.76 & 2.14 & 17.69 & -8.42 & -0.65 & -5.32 & -5.32 & -5.32 & -5.32 & -3.45 \\
\hline EPH & -132.92 & 2.52 & 10.61 & -4.96 & -4.53 & 2.51 & 2.51 & 2.51 & 2.51 & 2.08 \\
\hline
\end{tabular}

Economic weights used with the selection indices: $\mathrm{CV}_{\mathrm{g}}=$ coefficient of genetic variation; $\mathrm{SD}_{\mathrm{g}}=$ genetic standard deviation; $\mathrm{CV}_{\mathrm{g}} / \mathrm{CV}_{\mathrm{e}}=$ ratio $\mathrm{CV}_{\mathrm{g}} / \mathrm{CV}_{\mathrm{e}}$, where $\mathrm{CV}_{\mathrm{e}}$ is the coefficient of experimental variation; $\mathrm{h}^{2}{ }^{\mathrm{g}}=$ heritability; $\mathrm{AEW}$ $=$ tentatively assigned random weights $(1,10,20,1,100,100,1,1,1,1,1,15,25,15) . \mathrm{NE}=$ mean number of ears; $\mathrm{ND}=$ mean number of diseased ears; $\mathrm{NP}=$ mean number of ears attacked by pests; $\mathrm{EW}=$ mean weight of ears with grain; GY = grain yield; $\mathrm{PE}=$ popping expansion; $\mathrm{W} 100=$ mean weight 0 100 grains; FLOW = mean number of days to flowering; $\mathrm{PH}=$ mean plant height; $\mathrm{EH}=$ mean ear height; $\mathrm{FS}=$ final stand; $\mathrm{NBP}=$ mean number of broken plants; NLP = mean number of lodged plants; $\mathrm{EPH}=$ mean number of ears with poor husk cover.

When the economic weights $\mathrm{SD}_{\mathrm{g}}$ and $\mathrm{CV}_{\mathrm{g}}$ were used, gains were negative only for the ND trait. The gains for the traits NP, $\stackrel{\mathrm{g} L O W}{\mathrm{PH}}, \mathrm{g}, \mathrm{EH}, \mathrm{NBP}, \mathrm{NLP}$, and EPH were positive, which is not interesting for population improvement, since all negative traits of a cultivar (higher quantity of lodged and broken plants and of ears with poor husk cover) will be expressed in the new population, which will consequently have low yield and grain quality and, certainly, low popping expansion.

In an evaluation of the economic weight (AEW), it was noted that the gains of the traits ND, NP, FLOW, PH, EH, NBP, EPH, and NLP were negative, which is interesting for population improvement, since the gains for the traits NE, EW, GY, PE, and NP were positive. In this respect, when using the selection index of Mulamba and Mock (1978), assigning random weights, gains were higher. Vilarinho et al. (2003) evaluated the efficiency of truncated selection, with the indexes of Smith (1936) and Hazel (1943), of Williams (1962), of Pesek and Baker (1969), of Mulamba and Mock (1978), and of Elston (1963) for the 
identification of S1 and S2 progeny of improved popcorn, and concluded that for 30 and 60 families the most recommended selection strategy is the Mulamba and Mock (1978) index with the most satisfactory gains in yield and popping expansion. The economic weights for grain yield and popping expansion used were 1:1, 1:2 and 1:10, for $\mathrm{S} 1$ families; 1:1, 1:3 and $1: 10$, in the case of S2 progenies, respectively. The economic weights for grain yield and popping expansion used were respectively $1: 1,1: 2$ and 1:10 for $\mathrm{S} 1$ families, and 1:1, 1:3 and 1:10 in the case of S2 progeny. In a comparison of the efficiency of a number of selection indexes and the gains predicted by each one, to improve cold resistance in two maize populations, Crosbie et al. (1980) observed that the best gains in all traits were possible with the selection index of Mulamba and Mock (1978). We also believe that this index has the advantages of not being affected by inequality of the trait variances, as well as the simplicity of use and not requiring the estimation of genetic parameters, despite being less robust in terms of gains than the classic index of Smith (1936) and Hazel (1943).

Based on the index of Smith (1936) and Hazel (1943), simultaneous gains were predicted for the two main traits (PE and GY) with all assigned economic weights (Table 1). When the economic weights were $\mathrm{CV}_{\mathrm{g}}, \mathrm{SD}_{\mathrm{g}}$, the ratio $\mathrm{CV}_{\mathrm{g}} / \mathrm{CV}_{\mathrm{e}}$ and heritability, the predicted gains were equal for all traits, demonstrating that the values were not discrepant enough to cause changes in gains.

One of the highest gains for GY $(11.17 \%)$ was predicted by this index. Of all the economic weights used, NP, NBP and EPH had small positive gains, which is not desirable, because in the following cycle the population tends to have a greater number of ears attacked by pests and of broken plants and more ears with poor husk cover.

The gains predicted for the traits, ND, FLOW and NLP were negative, which is interesting because the target population would be less attacked by diseases and have fewer lodged plants and earlier flowering. For GY, gains were higher than the best gain by the Mulamba and Mock (1978) index, but had a very low gain for popping expansion when compared with that obtained by the index of Mulamba and Mock (1978).

Cruz et al. (1993) achieved simultaneous gains in the traits oil content and ear productivity in full-sib progeny of common corn by selection indices, which was not possible when using direct and indirect selection.

In this study, the key index of the sum of ranks of Mulamba and Mock (1978), achieved higher gains, which were better distributed among the traits. The 30 best genotypes were therefore selected by the index of Mulamba and Mock (1978), which maintained the genetic gain for PE and GY while producing negative gains for ND, NP, PH, EH, NBP, NLP, and EPH (Table 1).

Regarding the more important agronomic traits - grain yield and popping expansion - the means and limits (Table 2), a comparison of the means of the control (BRS Angela) with the means of the selected progeny shows that for the GY trait the means of the selected plants were $30.0 \%$ higher than that of the control. For PE, the variety BRS Angela exceeded the mean of the selected progeny by $7.31 \%$, which is not an important factor, since BRS Angela is a variety that has already been recommended by EMBRAPA-Milho e Sorgo. For other traits, the control means were lower than that of the selected progeny, as in the case of ND and NP, which is favorable for improvement, since the disease index and ears attacked by pests tend to be lower in the families.

The estimated gains with the selection of full-sib families were negative for NBP, NLP and 
$\mathrm{EPH}$, which is favorable for the breeding of an improved population, where the number of diseased plants, of plants attacked by insects and of those with partially hulled ears tend to be lower.

Table 2. Estimates of means of the original population $\left(\bar{X}_{o}\right)$, selected families $\left(\bar{X}_{s}\right)$, controls $\left(\bar{X}_{T}\right)$, lower (LL), and upper limit (UL) of progeny in the fourth cycle of intrapopulation recurrent selection of popcorn full-sib families for the two most important economical traits evaluated in two distinct environments (Campos dos Goytacazes and Itaocara, 2006).

\begin{tabular}{lrrrrr}
\hline Trait & $\bar{X}_{o}$ & $\bar{X}_{s}$ & $\bar{X}_{T}$ & LL & UL \\
\hline GY & $2,393.98$ & $2,772.50$ & $1,955.00$ & 670.00 & $4,510.00$ \\
PE & 25.06 & 28.00 & 30.21 & 11.20 & 35.90 \\
\hline
\end{tabular}

$\mathrm{GY}=$ grain yield; $\mathrm{PE}=$ popping expansion.

According to Freitas Júnior et al. (2009), the percentage gains with truncation selection were highest, in decreasing order, for EW, PE and GY $(20.23,10.58$ and $7.71 \%$, respectively). In other words, the expectation for C5 is to contain genotypes with PE of $30.80 \mathrm{~mL} / \mathrm{g}$ and GY of 2,986.25 kg/ha. With the aim of releasing a variety, these values are acceptable, and therefore, it is expected that the population of the next recurrent selection cycle can be recommended to producers in the northern and northwestern part of the State of Rio de Janeiro.

\section{ACKNOWLEDGMENTS}

Research supported by Conselho Nacional de Desenvolvimento Científico e Tecnológico $(\mathrm{CNPq})$ and Fundação Carlos Chagas Filho de Amparo à Pesquisa do Estado do Rio de Janeiro (FAPERJ).

\section{REFERENCES}

Aguiar CG, Schuster I, Amaral AT Jr, Scapim CA, et al. (2008). Heterotic groups in tropical maize germplasm by test crosses and simple sequence repeat markers. Genet. Mol. Res. 7: 1233-1244.

Bezerra Neto FV, Leal NR, Costa FR, Gonçalves GM, et al. (2006). Biometric analysis of squash lines. [Análise biométrica de linhagens de abóbora]. Hortic. Bras. 24: 378-380.

Crosbie TM, Mock JJ and Smith OS (1980). Comparison of gains predicted by several selection methods for cold tolerance traits of two maize populations. Crop Sci. 20: 649-655.

Cruz CD (2006). Biometria. Editora Universidade Federal de Viçosa, Viçosa.

Cruz CD and Carneiro PCS (2003). Modelos Biométricos Aplicados ao Melhoramento Genético. Editora da Universidade Federal de Viçosa, Viçosa.

Cruz CD, Vencovsky R, Silva SO and Tosello GA (1993). Comparison of gains from selection among corn progenies, based on different criteria. Rev. Bras. Genet. 16: 79-89.

Daros M, Amaral Júnior AT and Pereira MG (2002). Genetic gain for grain yield and popping expansion in full-sib recurrent selection in popcorn. Crop Breed. Appl. Biotechnol. 2: 339-344.

Daros M, Amaral Júnior AT, Pereira MG, Santos FS, et al. (2004a). Recurrent selection in inbred popcorn families. Sci. Agric. 61: 609-614.

Daros M, Amaral Júnior AT, Pereira MG, Santos FS, et al. (2004b). Correlations among agronomic traits in two recurrent selection cycles in popcorn. Cienc. Rural 34: 1389-1394.

Elston RC (1963). A weight-free index for the purpose of ranking or selection with respect to several traits at a time. Biometrics 19: 85-97.

Freitas Júnior SP, Amaral Júnior AT, Pereira MG, Cruz CD, et al. (2006). Combining ability in popcorn by circulant diallel. [Capacidade combinatória em milho-pipoca por meio de dialelo circulante]. Pesq. Agropec. Bras. 41: 1599-1607. 
Freitas Júnior SP, Amaral Júnior AT, Rangel RM and Viana AP (2009). Genetic gains in popcorn by full-sib recurrent selection. Crop Breed. Appl. Biotechnol. 9: 1-7.

Granate MJ, Cruz CD and Pacheco CAP (2002). Prediction of genetic gain with different selection indexes in popcorn CMS-43. [Predição de ganho genético com diferentes índices de seleção no milho pipoca CMS-43]. Pesq. Agropec. Bras. 37: 1001-1008.

Hazel LN (1943). The genetic basis for constructing selection indexes. Genetics 28: 476-490.

Kantety RV, Zeng S, Bennetzen JL and Zehr BE (1995). Assessment of genetic diversity in dent and popcorn (Zea mays L.) inbred lines using inter-simple sequence repeat (ISSR). Mol. Breed. 1: 365-373.

Miranda GV, Souza LV, Galvão JCC, Guimarães LJM, et al. (2008). Genetic variability and heterotic groups of Brazilian popcorn populations. Euphytica 162: 431-440.

Mulamba NN and Mock JJ (1978). Improvement of yield potential of the Eto Blanco maize (Zea mays L.) population by breeding for plant traits. Egypt. J. Gen. Cytol. 7: 40-51.

Munhoz RE, Prioli AJ, Amaral AT Jr, Scapim CA, et al. (2009). Genetic distances between popcorn populations based on molecular markers and correlations with heterosis estimates made by diallel analysis of hybrids. Genet. Mol. Res. 8: 951-962.

Pacheco CAP, Gama EP, Guimarães PEO, Santos MX, et al. (1998). Genetic parameters estimatives in CMS-42 and CMS-43 popcorn populations. [Estimativas de parâmetros genéticos nas populações CMS-42 e CMS-43 de milho de pipoca]. Pesq. Agropec. Bras. 33: 1995-2001.

Pereira MG and Amaral Júnior AT (2001). Estimation of genetic components in popcorn based on the nested design. Crop Breed. Appl. Biotechnol. 1: 3-10.

Pesek J and Baker RJ (1969). Desired improvement in relation to selected indices. Can. J. Plant Sci. 49: 803-804.

Rangel RM, do Amaral Junior AT, Viana AP and de Paiva Freitas Junior S (2007). Prediction of popcorn hybrid and composite means. Crop Breed. Appl. Biotechnol. 7: 287-295.

Rangel RM, Amaral AT Jr, Scapim CA, Freitas SP Jr, et al. (2008). Genetic parameters in parents and hybrids of circulant diallel in popcorn. Genet. Mol. Res. 7: 1020-1030.

Santos FS, Amaral Júnior AT, Freitas Júnior SP, Rangel RM, et al. (2007). Genetic gain prediction by selection index in a UNB-2U popcorn population under recurrent selection. [Predição de ganhos genéticos por índices de seleção na população de milho-pipoca UNB-2U sob seleção recorrente]. Bragantia 66: 389-396.

Santos FS, Amaral Júnior AT, Freitas Júnior SP, Rangel RM, et al. (2008). Genetic gain prediction of the third recurrent selection cycle in a popcorn population. Acta Sci. Agron. 30: 651-655.

SAS (Statistical Analysis System) (1995). SAS User's Guide: Statistics. SAS Institute, Cary.

Sawazaki E (2001). A cultura do milho pipoca no Brasil. Agronômico 53: 11-13.

Scapim CA, Braccini AL, Pinto RJB, Amaral Júnior AT, et al. (2006). Average genetic components and inbreeding depression in popcorn populations. [Componentes genéticos de medidas e depressão por endogamia em populações de milho-pipoca]. Cienc. Rural 36: 36-41.

Smith HF (1936). A discriminant function for plant selection. Ann. Eugen. 7: 240-250.

Tardin FD, Pereira MG, Gabriel APC, Amaral Júnior AT, et al. (2007). Selection index and molecular markers in reciprocal recurrent selection in maize. Crop Breed. Appl. Biotechnol. 7: 225-233.

Viana JMS and Matta FP (2003). Analysis of general and specific combining abilities of popcorn populations, including selfed parents. Genet. Mol. Biol. 26: 465-471.

Vieira RA, Souza Neto IL, Bignotto LS, Cruz CD, et al. (2009a). Heterotic parametrization for economically important traits in popcorn. Acta Sci. Agron. 31: 411-419.

Vieira RA, Rodovalho MA, Scapim CA, Tessmann DJ, et al. (2009b). Agronomic performance of new popcorn hybrids in Northwestern Paraná State, Brazil. Acta Sci. Agron. 31: 29-36.

Vilarinho AA, Viana JMS, Santos JF and Câmara TMM (2003). Efficiency in selecting $\mathrm{S}_{1}$ and $\mathrm{S}_{2}$ popcorn progenies for development of inbred lines. [Eficiência da seleção de progênies S1 e S2 de milho-pipoca, visando à produção de linhagens]. Bragantia 62: 9-17.

Vilela FO, Amaral Júnior AT, Pereira MG, Scapim CA, et al. (2008). Effect of recurrent selection on the genetic variability of the UNB-2U popcorn population using RAPD markers. [Efeito da seleção recorrente na população UNB-2U de milho pipoca por marcadores RAPD]. Acta Sci. Agron. 30: 25-30.

Williams JS (1962). The evaluation of a selection index. Biometrics 18: 375-393. 